\section{Yield and Disease Resistance for Three Bacterial Wilt-resistant Tomato Rootstocks}

\author{
David H Suchoff ${ }^{1,3}$, Frank J. Louws ${ }^{2}$, and Christopher C. Gunter ${ }^{2}$
}

ADDITIONAL INDEX WORDs. grafting, on-farm, Ralstonia solanacearum, Solanum lycopersicum, yield

SUMMARY. Interest and use of grafted tomato (Solanum lycopersicum) in the United States continues to grow. Pioneered in Asia, herbaceous grafting is a commonly used cultural practice to manage many soilborne pathogens. Bacterial wilt (BW), caused by the pathogen Ralstonia solanacearum, is an aggressive soilborne pathogen that affects tomato grown in the southeastern United States. Traditional fumigation methods have limited effectiveness in the management of this pathogen. The present study was conducted to compare the bacterial wilt resistance of three commercially available tomato rootstocks, which are purported to be resistant to bacterial wilt: 'Cheong Gang', 'RST-04-106-T', and 'Shield'. The determinate hybrid tomato 'Red Mountain', which is susceptible to bacterial wilt, was used as the scion and nongrafted control. Three locations were used over 2 years in North Carolina: an on-farm site with a history of bacterial wilt and two North Carolina Department of Agriculture Research Stations with no recent history of bacterial wilt. No disease symptoms were observed in any of the three grafted treatments, whereas the nongrafted controls showed between $30 \%$ and $80 \%$ disease incidence at the on-farm location. The resultant rootstock-imparted resistance improved marketable yields by between $88 \%$ and $125 \%$ compared with the nongrafted plants. When grown in locations lacking BW there were no yield benefits to grafting with any of the three rootstocks.

$\mathrm{V}$ alued at $\$ 1.24$ billion, fresh market tomato is the second most valuable vegetable crop grown in the United States [U.S. Department of Agriculture (USDA), 2016]. The southeastern United States accounts for $\approx 52 \%$ of the total planted acreage in the United States, which has a total value of $\$ 699$ million. Ralstonia solanacearum race $l$ is an economically devastating soilborne pathogen that affects tomato throughout the southeastern United States (Ji et al., 2007;

Received for publication 19 Feb. 2019. Accepted for publication 20 Mar. 2019

Published online 22 April 2019.

We thank the staff at the Horticultural Crops Research Station and Piedmont Research Station for their maintenance of field trials. Additionally, we thank Ontario Plants Propagation Limited for providing grafted plants for this study. This material is based on work that is supported by the National Institute of Food and Agriculture, U.S. Department of Agriculture, under award number 2011-01397.

${ }^{1}$ Department of Crop and Soil Sciences, North Carolina State University, 2721 Founders Drive, Raleigh, NC 27695

${ }^{2}$ Department of Horticultural Science, North Carolina State University, 2721 Founders Drive, Raleigh, NC 27695

${ }^{3}$ Corresponding author. E-mail: dhsuchof@ncsu.edu. This is an open access article distributed under the CC BY-NC-ND license (https://creativecommons.org/ licenses/by-nc-nd/4.0/).

https://doi.org/10.21273/HORTTECH04318-19
McAvoy et al., 2012). Soil fumigation with traditional fumigants, such as chloropicrin and the now banned methyl bromide, have proven ineffective in the management of this pathogen (Chellemi et al., 1997; Driver and Louws, 2002; Enfinger et al., 1979).

Grafting of susceptible tomato cultivars onto resistant rootstocks is an effective cultural technique for managing BW (McAvoy et al., 2012; Rivard and Louws, 2008). This practice is widely used throughout many Asian and Mediterranean countries where intensive greenhouse production is prevalent (Besri, 2001; Cohen et al., 2007; Lee, 2003; Lee et al., 1998). Interest in grafting continues to increase in the United States, and demand for grafted plants has led to the establishment of grafting-specific facilities.

Currently, at least 65 tomato rootstocks have been developed by commercial breeders (USDA, 2014). Many of these rootstocks contain the same resistance packages; for example, 20 of the 65 rootstocks are purported to be resistant to BW. Limited comparative research exists evaluating many of these rootstocks, thus growers face challenges when deciding which rootstock to use. Furthermore, levels of BW resistance among certain rootstocks do not appear to be equal (McAvoy et al., 2012). McAvoy et al. (2012) noted that certain rootstocks may improve yield compared with nongrafted plants when grown in conditions with low amounts of $\mathrm{BW}$. Research using grafted tomato grown in greenhouses and openfield conditions lacking any history of soilborne pathogens has shown that certain rootstocks can increase fruit size, weight, and count compared with nongrafted controls (Kyriacou et al., 2017). Whether the improved yield from grafted plants in locations with low amounts of BW observed by McAvoy et al. (2012) was due to differing BWresistance mechanisms or a more general rootstock-mediated yield increase is unknown.

To address the lack in information on commercially available BWresistant rootstocks, we conducted the following study with the objectives of 1 ) assessing BW resistance of three resistant rootstocks in a commercial tomato field with known history of BW infestation, 2) determine whether there are yield benefits or penalties when using these rootstocks in conditions with no recent history of BW in open field production, and 3 ) compare the effects of grafting on yield in different climatic regions of North Carolina.

\begin{tabular}{llll}
\hline $\begin{array}{l}\text { Units } \\
\text { To convert U.S. to SI, } \\
\text { multiply by }\end{array}$ & U.S. unit & SI unit & $\begin{array}{l}\text { To convert SI to U.S., } \\
\text { multiply by }\end{array}$ \\
\hline 0.4047 & $\mathrm{acre}(\mathrm{s})$ & $\mathrm{ha}$ & $2.471 \mathrm{l}$ \\
0.3048 & $\mathrm{ft}$ & $\mathrm{m}$ & 3.2808 \\
2.54 & inch(es) & $\mathrm{cm}$ & 0.3937 \\
0.4536 & $\mathrm{lb}$ & $\mathrm{kg}$ & 2.2046 \\
1.1209 & $\mathrm{lb} / \mathrm{acre}$ & $\mathrm{kg} \cdot \mathrm{ha}^{-1}$ & 0.8922 \\
2.2417 & ton $(\mathrm{s}) / \mathrm{acre}$ & $\mathrm{Mg} \cdot \mathrm{ha}^{-1}$ & 0.4461 \\
$\left({ }^{\circ} \mathrm{F}-32\right) \div 1.8$ & ${ }^{\circ} \mathrm{F}$ & ${ }^{\circ} \mathrm{C}$ & $\left({ }^{\circ} \mathrm{C} \times 1.8\right)+32$
\end{tabular}




\section{Materials and methods}

Trial Locations. Three field sites were used in both 2015 and 2016. The locations chosen were a commercial farm with a history of BW and two North Carolina Department of Agriculture Research Stations [Piedmont Research Station (PRS), Salisbury (lat. $35.41^{\circ} \mathrm{N}$, long. $80.37^{\circ} \mathrm{W}$ ) and Horticultural Crops Research Station (HCRS), Clinton, $\mathrm{NC}$ (lat. $35.01^{\circ} \mathrm{N}$, long. $78.16^{\circ} \mathrm{W}$ )]. The grower cooperator noted that previous crop loss due to $\mathrm{BW}$ at the on-farm field location (OF) has been as high as $30 \%$ to $40 \%$ in previous years. Both the PRS and OF are located in the Piedmont region of North Carolina; however, PRS lacks the BW pressure of OF. HCRS is located in the Coastal Plain region of North Carolina. HCRS and PRS were chosen as they represent the two largest vegetable producing regions in North Carolina. Average temperatures for both locations and years were similar, with average highs close to $30{ }^{\circ} \mathrm{C}$; however, HCRS experienced more rain events throughout the growing season in 2015 and 2016 (Fig. 1).

EXPERIMENTAL TREATMENTS. The determinate hybrid tomato cultivar Red Mountain (Harris Seeds, Rochester, NY) was used as the nongrafted control (RM) and scion for all grafted treatments because it is susceptible to BW and the preferred cultivar by the OF proprietor to meet their market demand. 'Red Mountain' is a hybrid bush type tomato that produces fruit that are round, deep red, and have smooth shoulders. Three BW resistant rootstocks were used: 'RST-04-106-T' (R/RM; DP Seeds, Yuma, AZ), 'Shield' (S/RM; Rijk Zwaan, Salinas, CA), and 'Cheong Gang' (CG/RM; Seminis Vegetable Seeds, St. Louis, MO). Grafted plants were supplied by Ontario Plants Propagation Limited (St. Thomas, ON, Canada), and the nongrafted plants were supplied by the proprietor of the OF location. Scions were initially pruned to two leaders and the nongrafted control to one, which is the commercial standard practice for the production area (Fig. 2). The use of double- and single-leader plants follows the OF norms for grafted and nongrafted
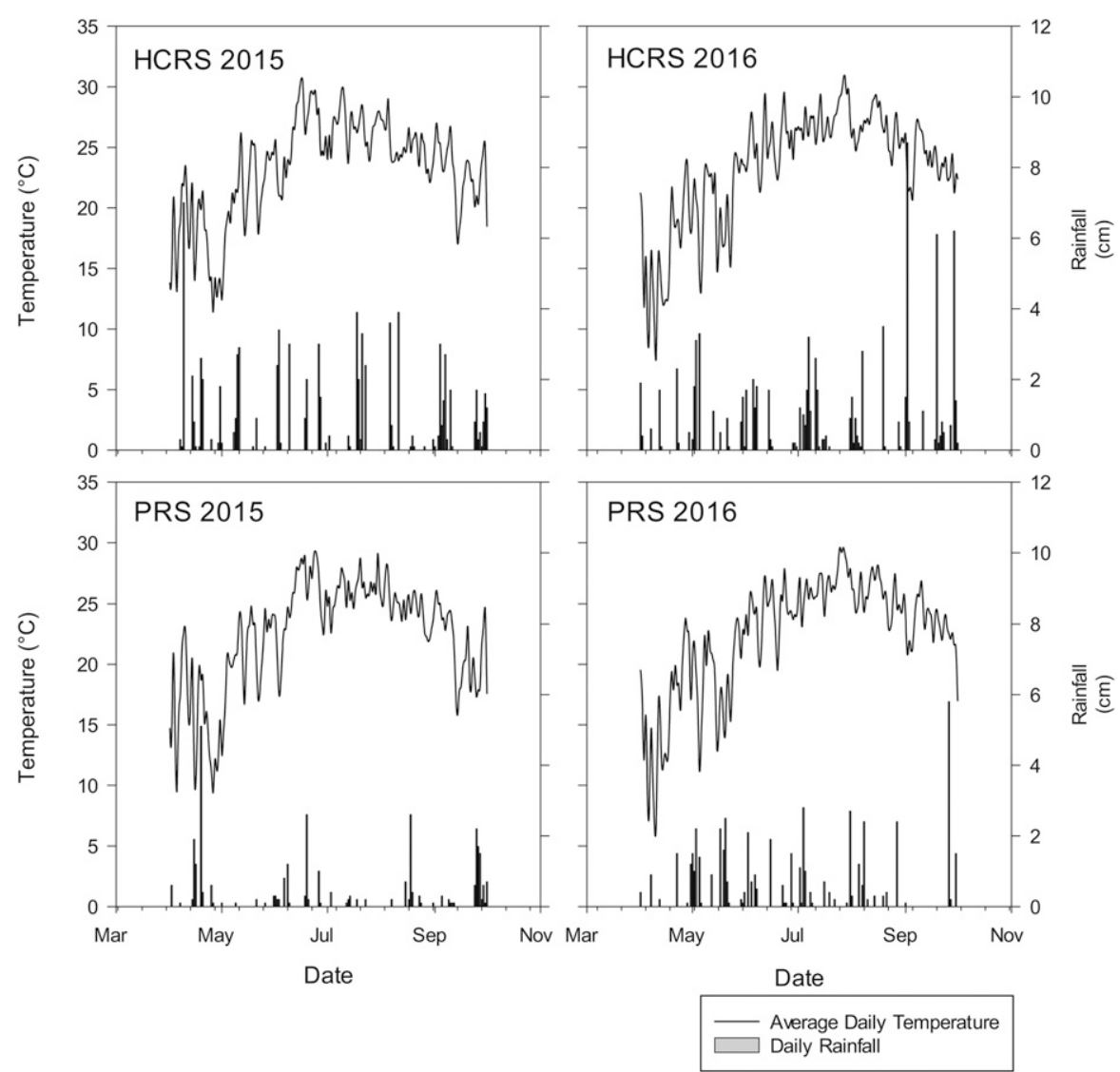

Fig. 1. Average daily temperature and daily rainfall for 2015 and 2016 at the Horticultural Crops Research Station in Clinton, NC (HCRS) and Piedmont Research Station in Salisbury, NC (PRS). Data collected from the North Carolina state climate office; $\left(1.8 \times{ }^{\circ} \mathrm{C}\right)+32={ }^{\circ} \mathrm{F}, 1 \mathrm{~cm}=0.3937$ inch.

plants in production, respectively. Although the nongrafted and grafted plants were supplied from different locations and started in different media (Fig. 2), no appreciable differences in stand establishment or rate of growth were visually noted among the three locations. The only differences observed were in the nongrafted plants at $\mathrm{OF}$ due to disease incidence (Fig. 3).

Field LAYout. Soil type at HCRS was an Orangeburg sandy loam with $\mathrm{pH} 6.2$ and cation exchange capacity (CEC) of $4.0 \mathrm{meq} /$ $100 \mathrm{~cm}^{3}$. Soil type at PRS was Cecil sandy clay with $\mathrm{pH} 6.0$ and CEC of $7.6 \mathrm{meq} / 100 \mathrm{~cm}^{3}$. OF and PRS shared the same soil types. Preplant soil fumigation of $147 \mathrm{lb} /$ acre chloropicrin $+86 \mathrm{lb} /$ acre 1,3-dichloropropene (PicChlor-60; Cardinal Professional Products, Hollister, CA) occurred both years at PRS and HCRS. Fields with a history of severe BW were chosen at OF and were not fumigated. Prebedding lime and

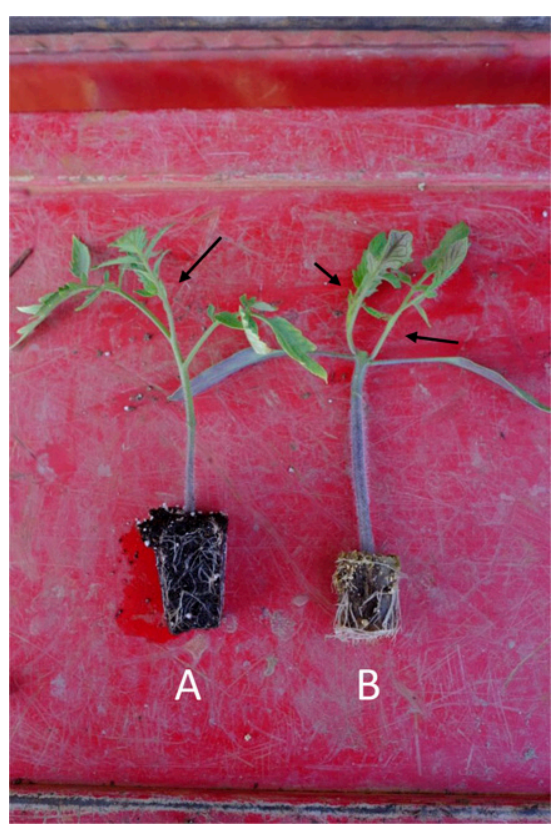

Fig. 2. Transplants of nongrafted tomato with single leader (A) and grafted tomato with double leaders (B). Arrows indicate location of leaders. 
fertilizer application followed the North Carolina Department of Agriculture and Consumer Services Agronomic Division recommendations based on soil test results (Hardy et al., 2014). Weekly fertigation and pesticide applications followed standard management practices for the southeastern United States (Kemble et al., 2016). Each location was arranged in a randomized complete block design with four blocks. Individual blocks consisted of a raised

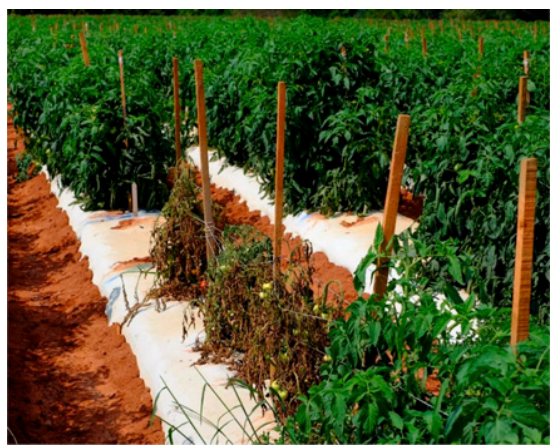

Fig. 3. Nongrafted tomato plants showing severe bacterial wilt symptoms at the on-farm location in Salisbury, NC in naturally infested soils. bed 6 inches high by $5 \mathrm{ft}$ wide and were prepared under North Carolina standard plasticulture protocols (Ivors, 2010). Beds at HCRS and PRS were spaced 60 inches apart and 56 inches apart at OF. Each block was divided into four 18 -ft-long plots to which the four experimental treatments were randomized. Plots consisted of 10 plants spaced 21 inches apart. In 2015 , transplanting occurred on 9 July at PRS and OF, and 10 July at HCRS. In 2016, transplanting occurred on 1 June at PRS and OF and 2 June at HCRS. One initial pruning occurred to remove suckers early in the season and plants were trained using the stake and weave method (Kemble et al., 2016).

Data Collection. Stand counts based on the number of plants unaffected by BW were collected during harvest at $\mathrm{OF}$ (Fig. 3). Two to three harvests per location occurred at the end of the season once fruit reached the mature green/early breaker stage (USDA, 1991). Fruit were separated into three diameter size grades based on OF proprietor marketability standards: small (2.0-3.0 inches), medium (>3.0-3.5 inches), and large (>3.5 inches). Count and weight for

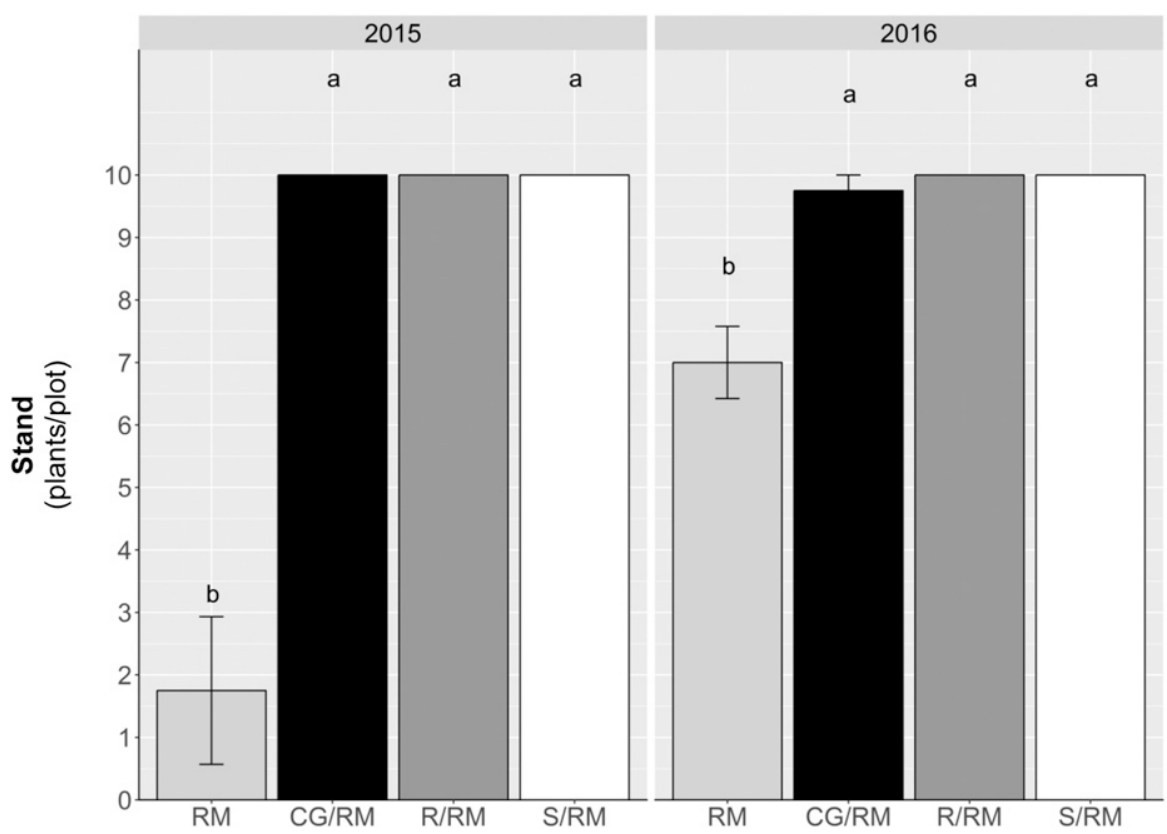

Fig. 4. Mean number of healthy tomato plants $( \pm S E)$ per 10-plant plot at on-farm location in Salisbury, NC. Means with same letters within a year are not different (Tukey's honestly significant difference at $\alpha=0.05$ ) and represent the average of four replicate samples $(n=4$ data points for each mean). Effect of grafting was significant $(P<0.05)$ for both years; $R M=$ 'Red Mountain' nongrafted, $C G / R M=$ 'Red Mountain' on 'Cheong Gang' rootstock, $\mathrm{R} / \mathrm{RM}$ = 'Red Mountain' on 'RST04-106- $\mathrm{T}$ ' rootstock, $S / \mathrm{RM}$ = 'Red Mountain' on 'Shield' rootstock. each grade was collected. Additionally, the combined weights and counts for all three grades were calculated and represent total marketable fruit. Any fruit rendered unmarketable due to disease or damage were designated as culls and their weight collected.

Statistical analysis. All data were analyzed using the GLIMMIX procedure in SAS (version 9.3; SAS Institute, Cary, NC). Data were initially analyzed by location with treatment and year as a fixed effects; however, there was no significant year $\times$ treatment interaction $(P>$ 0.05 ) for any of the response variables, and thus years were combined. The final model for yield responses contained the fixed effect for grafting treatment and random effects for year and block nested in year. Stand count at OF was analyzed by year to account for potentially different levels of BW infestation. Residual plots for weight data showed strong heteroscedasticity, which was resolved through a square root transformation of the data. Due to the nonnormal nature of count data, both stand count and fruit counts were analyzed using a negative binomial distribution and the canonical log link in PROC GLIMMIX. This distribution was chosen over the Poisson distribution because the latter showed strong overdispersion, whereas the negative binomial distribution proved a better fit $[\varphi=1.0$ (Gardner et al., 1995)]. When appropriate, Tukey's honestly significant difference was used as a post hoc mean separation test, and, for reporting, data were back-transformed.

\section{Results}

There was a significant effect on stand count due to grafting at OF in 2015 and 2016 (Fig. 4). There were no differences among the rootstocks in stand count, but RM had losses of $81 \%$ and $30 \%$ in 2015 and 2016 , respectively (Fig. 4). In 2016, one $\mathrm{CG} / \mathrm{RM}$ plant died due to $\mathrm{BW}$; on inspection, it became evident that this death was the result of adventitious roots from the scion coming in contact with the soil due to improper staking.

All yield responses, other than cull weight, at OF were affected by grafting (Table 1). For small, medium, and marketable fruit counts and weights, there were no differences 
among the rootstocks, but all were significantly greater than RM (Figs. 5 and 6). Marketable fruit weight in RM was $48 \%$ to $56 \%$ lower than the three grafted treatments. Marketable fruit count followed a similar pattern of $48 \%$ to $53 \%$ fewer fruit in RM compared with the grafted treatments. Largegrade fruit accounted for the smallest proportion of marketable fruit. Large fruit weight was highest in R/RM but not different from the other two grafted treatments. RM had the lowest large fruit weight, but this was not different from S/RM. Less separation was observed in large fruit count; RM had the lowest large fruit count, but this was not different from CG/RM or S/RM.

There were no differences among treatments for any of the yield responses at HCRS (Table 1). Similar results were observed at PRS other than for large fruit weight in which RM yielded less than $\mathrm{S} / \mathrm{RM}$ and $\mathrm{CG} / \mathrm{RM}$; however, this did not result in any difference in marketable fruit count or weight (Figs. 7 and 8).

\section{Discussion}

Grafting tomato onto resistant rootstocks offers growers a new option to manage economically significant soilborne pathogens in an environmentally conscious manner (Louws et al., 2010). Many of these diseasecausing pathogens were traditionally managed with methyl bromide; however, this soil fumigant was banned, which left growers with limited options with inconsistent results (Martin, 2003; U.S. Environmental Protection Agency, 2011). Management of $R$. solanacearum through soil fumigation has proven difficult, and fumigation may actually exacerbate infestation by reducing soil microbial diversity (Chellemi et al., 1996; Driver and Louws, 2002; Enfinger et al., 1979;

Table 1. One-way analysis of variance for fruit yield data of grafted and nongrafted tomato grown at Piedmont Research Station in Salisbury, NC (PRS); Horticultural Crops Research Station in Clinton, NC (HCRS); and on-farm location in Salisbury, NC (OF).

\begin{tabular}{|c|c|c|c|c|c|c|c|c|c|c|c|}
\hline Location & Source & df & $\begin{array}{l}\text { Small } \\
\text { count }^{\mathrm{z}}\end{array}$ & $\begin{array}{c}\text { Medium } \\
\text { count }^{\mathrm{z}}\end{array}$ & $\begin{array}{l}\text { Large } \\
\text { count }^{\mathrm{z}}\end{array}$ & $\begin{array}{c}\text { Marketable } \\
\text { count }^{\mathrm{z}}\end{array}$ & $\begin{array}{l}\text { Cull } \\
\text { wt }^{\mathrm{z}}\end{array}$ & $\begin{array}{c}\text { Small } \\
\text { wt }\end{array}$ & $\begin{array}{c}\text { Medium } \\
\text { wt }\end{array}$ & $\begin{array}{c}\text { Large } \\
\text { wt }\end{array}$ & $\begin{array}{c}\text { Marketable } \\
\text { wt }\end{array}$ \\
\hline PRS & Graft & 3 & NS & NS & NS & NS & NS & NS & NS & * & NS \\
\hline HCRS & Graft & 3 & NS & NS & NS & NS & NS & NS & NS & NS & NS \\
\hline OF & Graft & 3 & ** & * & * & ** & NS & $* * *$ & ** & ** & $* * *$ \\
\hline
\end{tabular}

${ }^{\mathrm{z}}$ Fruit grade sizes based on OF proprietor fruit diameter standards: small (2.0-3.0 inches), medium $(>3.0-3.5$ inches $)$, and large ( $>3.5$ inches); culls are any fruit $<2.0$ inches or damaged due to insect or mechanical injury; 1 inch $=2.54 \mathrm{~cm}$. Marketable fruit is the combination of small, medium, and large grades. NS, ${ }^{*}, * * * * *$ Nonsignificant at $P \leq 0.05$ or significant at $P \leq 0.05,0.01$, or 0.001 , respectively.
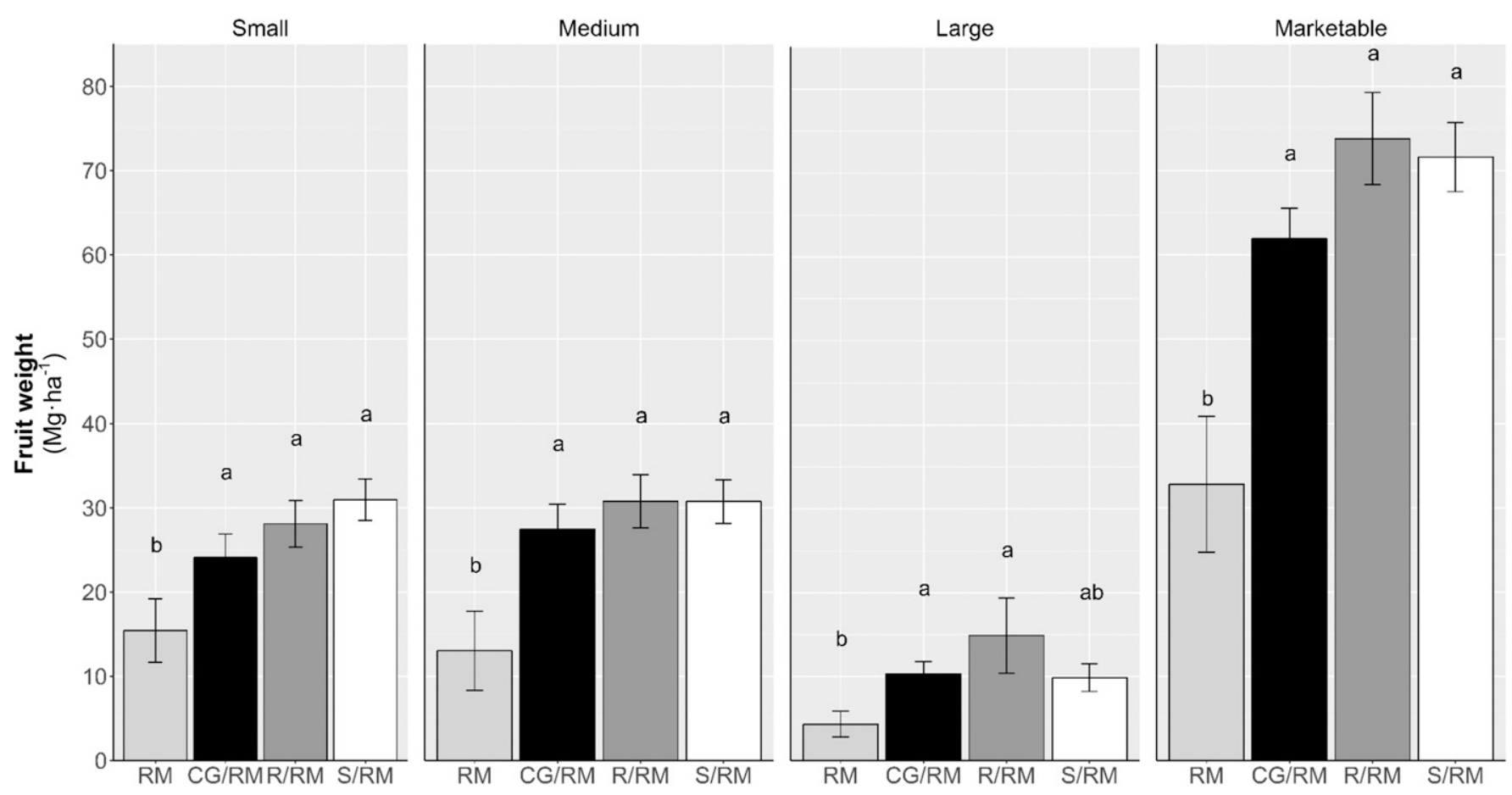

Fig. 5. Mean tomato fruit weight $( \pm S E)$ by grade at the on-farm location in Salisbury, NC. Means with same letters within a grade are not different (Tukey's honestly significant difference at $\alpha=0.05$ ) and represent the average of 2 years and four replicate samples $(n=8$ data points for each mean $) ; \mathrm{RM}=$ 'Red Mountain' nongrafted, $\mathrm{CG} / \mathrm{RM}=$ 'Red Mountain' on 'Cheong Gang' rootstock, $\mathrm{R} / \mathrm{RM}$ = 'Red Mountain' on 'RST-04-106-T' rootstock, S/RM = 'Red Mountain' on 'Shield' rootstock. Fruit grade sizes are based on on-farm proprietor fruit diameter standards: small (2.0-3.0 inches), medium (>3.0-3.5 inches), and large ( $>3.5$ inches); culls are any fruit $<2.0$ inches or damaged due to insect or mechanical injury. Marketable fruit is the combination of small, medium, and large grades; 1 inch $=2.54 \mathrm{~cm}, 1 \mathrm{Mg} \cdot \mathrm{ha}^{-1}=0.4461 \mathrm{ton} / \mathrm{acre}$. 

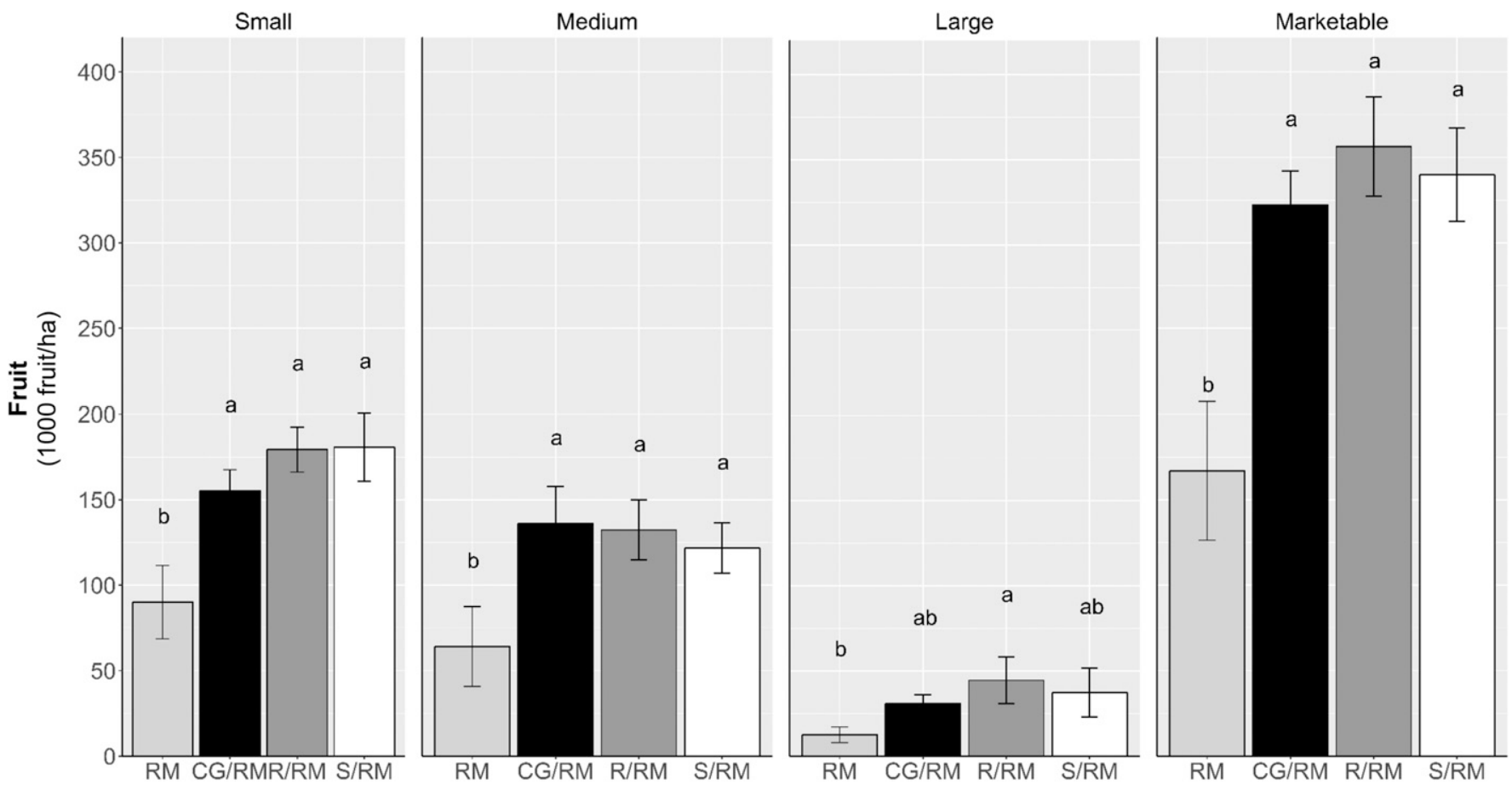

Fig. 6. Mean tomato fruit count $( \pm \mathrm{SE})$ by grade at the on-farm location in Salisbury, NC. Means with same letters within a grade are not different (Tukey's honestly significant difference at $\alpha=0.05$ ) and represent the average of 2 years and four replicate samples ( $\mathrm{n}=\mathbf{8}$ data points for each mean); $\mathrm{RM}=$ 'Red Mountain' nongrafted, $\mathrm{CG} / \mathrm{RM}=$ ' $\mathrm{Red}$ Mountain' on 'Cheong Gang' rootstock, $\mathrm{R} / \mathrm{RM}=$ 'Red Mountain' on 'RST-04-106-T' rootstock, $\mathrm{S} / \mathrm{RM}=$ 'Red Mountain' on 'Shield' rootstock. Fruit grade sizes are based on on-farm proprietor fruit diameter standards: small (2.0-3.0 inches), medium (>3.0-3.5 inches), and large (>3.5 inches); culls are any fruit $<2.0$ inches or damaged due to insect or mechanical injury. Marketable fruit is the combination of small, medium, and large grades; 1 inch $=2.54 \mathrm{~cm}, 1000 \mathrm{fruit} / \mathrm{ha}=404.6856 \mathrm{fruit} / \mathrm{acre}$.

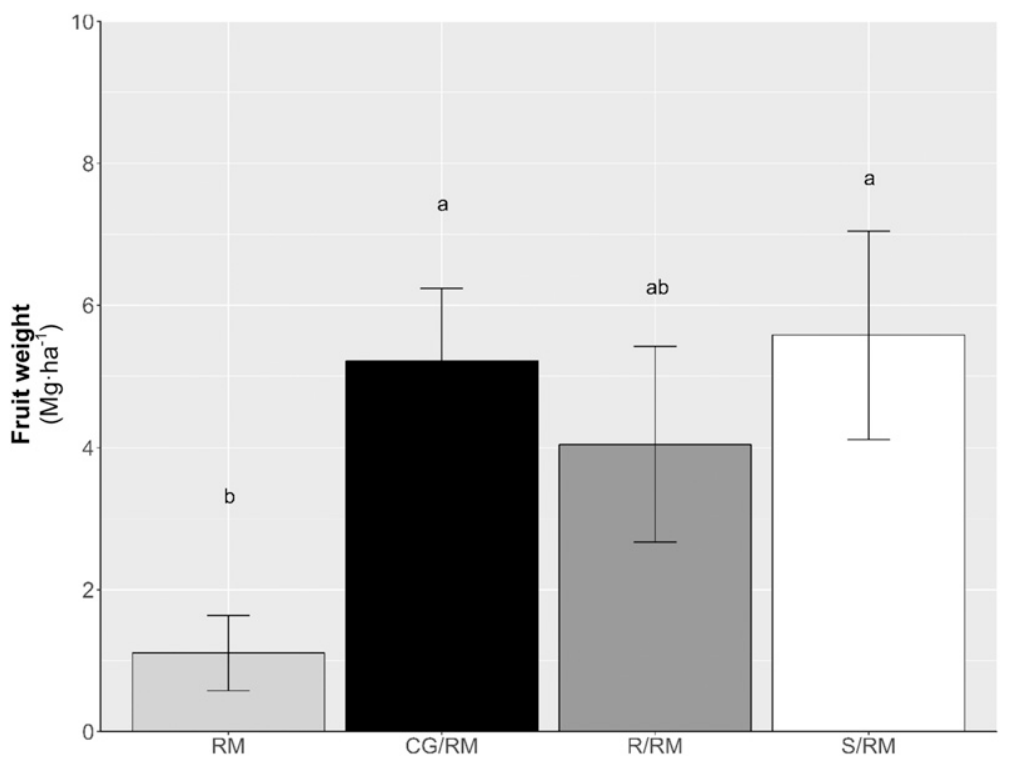

Fig. 7. Large tomato fruit weight $( \pm \mathrm{SE})$ at Piedmont Research Station in Salisbury, NC. Means with same letters are not different (Tukey's honestly significant difference; $\alpha=0.05$ ) and represent the average of 2 years and four replicate samples ( $n=8$ data points for each mean); $\mathbf{R M}=$ 'Red Mountain' nongrafted, $C G / R M=$ 'Red Mountain' on 'Cheong Gang' rootstock, $\mathrm{R} / \mathrm{RM}=$ 'Red Mountain' on 'RST04-106-T' rootstock, $S / R M$ = 'Red Mountain' on 'Shield' rootstock. Large fruit grade sizes based on on-farm proprietor fruit diameter standards of $>3.5$ inches $(8.89 \mathrm{~cm}) ; 1 \mathrm{Mg} \cdot \mathrm{ha}^{-1}=0.4461 \mathrm{ton} /$ acre.
Shiomi et al., 1999). Because $R$. solanacearum has a wide host range of both agronomic crops and common weed species, an effective crop rotation scheme is difficult (Hayward, 1991). Breeding for new tomato cultivars resistant to BW has been difficult because the genes associated with resistance appear to be strongly linked to small-fruited phenotypes (Scott et al., 2005; Wang et al., 1998). As such, a concerted effort has been aimed at cultural management practices, including grafting (Nion and Toyota, 2015).

Compared with traditional breeding of new resistant cultivars, grafting offers growers customizability; rootstocks can be selected on the basis of the pathogen(s) present and scions chosen to meet market demand. Grafting onto BW-resistant rootstocks is an effective management strategy for $R$. solanacearum. In a 2 -year study, Rivard and Louws (2008) showed that, when grown in infested soils, grafted 'German Johnson' onto BW resistant rootstocks 'CRA 66' and 'Hawaii 7996' 

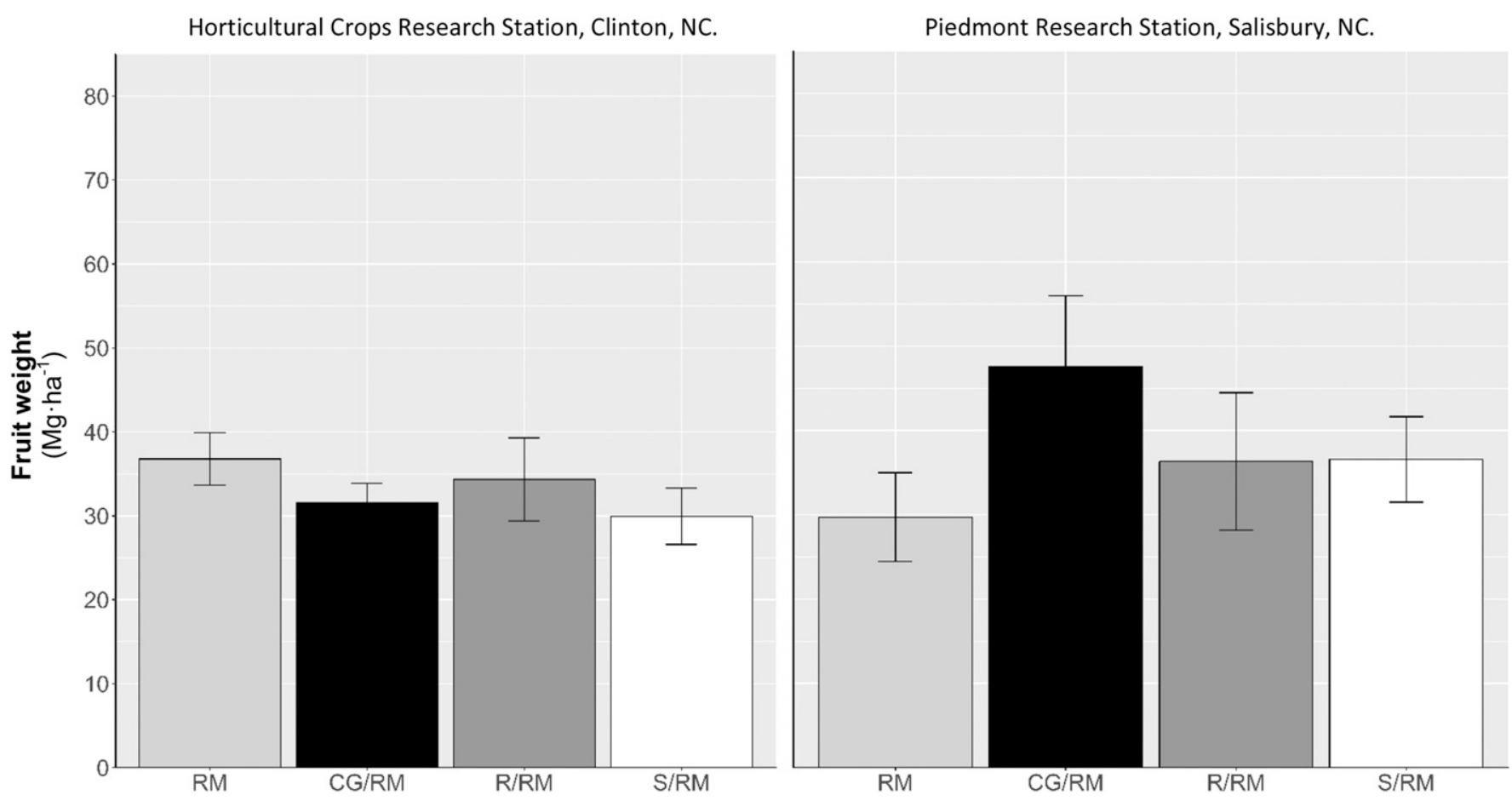

Fig. 8. Marketable tomato fruit weight $( \pm \mathrm{SE})$ for Horticultural Crops Research Station and Piedmont Research Station. Means represent the average of 2 years and four replicate samples $(n=8) ; R M=$ 'Red Mountain' nongrafted, CG $/ R M=$ 'Red Mountain' on 'Cheong Gang' rootstock, $R / R M=$ 'Red Mountain' on 'RST-04-106-T' rootstock, $S / R M=$ 'Red Mountain' on 'Shield' rootstock. Marketable fruit is the combination of small (2.0-3.0 inches diameter), medium (>3.0-3.5 inches diameter), and large (>3.5 inches diameter) grades; 1 inch $=2.54 \mathrm{~cm}, 1 \mathrm{Mg} \cdot \mathrm{ha}^{-1}=0.4461$ ton $/ \mathrm{acre}$.

effectively managed disease symptoms. These grafted plants showed no symptoms of disease compared with nongrafted 'German Johnson', which had $75 \%$ to $79 \%$ disease incidence, resulting in significantly higher marketable yield from the grafted plants. McAvoy et al. (2012) also found that BW can be managed through grafting when grown in naturally infested soils in Virginia and artificially infested soils in Florida. However, discrepancies in disease incidence in grafted plants were observed when comparing the two locations. Specifically, high levels of disease were seen in grafted plants in Florida, which the authors attributed to the much higher population of $R$. solanacearum due to artificial infestation. Disease incidence varied with rootstock in Florida: 'Cheong Gang' had $28.4 \%$ disease incidence and 'RST-04-106-T' had 57.8\% incidence. In the naturally infested soils of Virginia, disease incidence was $6.5 \%$ and $13.0 \%$ for 'Cheong Gang' and 'RST-04-106-T', respectively. In our study, these two rootstocks showed no disease incidence when grown in fields that resulted in $30 \%$ to
$81 \%$ disease incidence in the nongrafted control. To date, there is no published research evaluating 'Shield' rootstock in BW-infested soils. Our results indicate that 'Shield' is equally effective at managing BW as 'Cheong Gang' and 'RST-04-106-T'. These three rootstocks offer growers with fields infested with BW an effective means to manage the pathogen. Future research is needed to determine whether the resistance mechanisms of these rootstocks are the same. If these mechanisms are different, it may allow growers to rotate rootstocks to minimize selective pressure on the pathogen population.

The nongrafted control transplants contained one leader, whereas the grafted treatments contained double leaders (Fig. 2). As such, the number of leaders may have a confounding effect on the yield responses collected in this study. A prior study at the OF location investigated the effect of leader number on yield in grafted and nongrafted tomato (Suchoff et al., 2015). Results were inconclusive because leader number affected yield in a fumigated field ( $P=0.009)$ but not in a nonfumigated field $(P=0.191)$. Ara et al. (2007) found that nongrafted plants with double leaders yielded significantly more than singleleader, nongrafted plants; however, these results represent data from a single location and year, and as such, they lack the statistical robustness necessary for making any conclusive inferences. Because no marketable yield differences were observed among any of the treatments (Table 1) at HCRS and PRS, where BW was not present, it would appear that leader number did not affect marketable yield. However, further research is warranted to determine whether leader number and spacing can affect yield in grafted and nongrafted tomato in environments with no history of soilborne pathogens.

The high initial investment in grafted tomato transplants can be a barrier to entry for many growers; grafted transplants can cost up to $\$ 1.02 /$ plant compared with $\$ 0.12$ / plant for nongrafted plants (Rysin and Louws, 2015). Plant density at OF was 13,213 plants/ha. Using the 
published prices from Rysin and Louws (2015), it would cost $\$ 13,477.26 /$ ha for grafted transplants and $\$ 1585.56 /$ ha for nongrafted transplants, amounting to an investment of $\$ 11,891.70 /$ ha for the purchase of grafted transplants. The average marketable fruit yield for the grafted treatments $(\mathrm{CG} / \mathrm{RM}, \mathrm{S} / \mathrm{RM}$, and $\mathrm{R} / \mathrm{RM}$ ) was 69.11 and 32.79 $\mathrm{Mg} \cdot \mathrm{ha}^{-1}$ for the nongrafted control (RM) at the OF location (Fig. 5). Using the published sale price of $\$ 0.882 / \mathrm{kg}$ (Rysin and Louws, 2015), gross returns on marketable fruit would amount to $\$ 60,957.23 / \mathrm{ha}$ for the grafted treatments and $\$ 28,920.78 /$ ha for the nongrafted control. Taking into account initial transplant costs, net returns from the grafted treatments would amount to $\$ 47,479.97 / \mathrm{ha}$ and $\$ 27,335.22 / \mathrm{ha}$. As such, the rootstock-imparted disease resistance would allow for a net gain in revenue well above returns from susceptible nongrafted transplants even with the high initial price of grafted transplants.

Certain rootstocks have been shown to improve yield in conditions with no known history of BW. The hybrid rootstocks 'Maxifort' and 'Beaufort' can significantly increase yield compared with nongrafted controls (Di Gioia et al., 2010; Leonardi and Giuffrida, 2006; Mišković et al., 2009). McAvoy et al. (2012) noted a numerical but not significant increase in yield when using hybrid rootstocks in locations with very low disease incidence. Our current study showed no significant increase in yield due to grafting in two locations with no recent history of BW. Interestingly, we did observe that 'Cheong Gang' and 'Shield' rootstocks improved large fruit weight at PRS (Fig. 7). McAvoy et al. (2012) found similar results; under low levels of BW, 'Cheong Gang' produced significantly higher large fruit weight than nongrafted and self-grafted controls. The reason for this result is unclear and may be due to the complex interaction of rootstock genotype and environment because we did not observe these results at HCRS.

The significant increase in yield observed in the infested fields at $\mathrm{OF}$ appears to be due to rootstockimparted resistance and not necessarily to intrinsic vigor (Fig. 4). In two climatic regions of $\mathrm{NC}$, we found that these rootstocks added no appreciable benefit to marketable yield compared with nongrafted tomato. This study demonstrates the benefits of grafting onto 'Shield', 'Cheong Gang', and 'RST-04-106$\mathrm{T}$ ' rootstocks when grown in fields infested with BW. These rootstocks can allow growers to use infested land that may otherwise be abandoned and maintain their market share.

\section{Literature cited}

Ara, N., M.K. Bashar, S. Begum, and S.S. Kakon. 2007. Effect of spacing and stem pruning on the growth and yield of tomato. Intl. J. Sustainable Crop Production 2:35-39.

Besri, M. 2001. New developments of alternatives to methyl bromide for the control of tomato soilborne pathogens in covered cultivation in a developing country, Morocco. 2001 Annu. Intl. Res. Conf. Methyl Bromide Alternatives Emissions Reductions, San Diego, CA, 5-8 Nov. 2001. p. 12.

Cohen, R., Y. Burger, C. Horev, A. Koren, and M. Edelstein. 2007. Introducing grafted cucurbits to modern agriculture. The Israeli experience. Plant Dis. 91:916-923.

Chellemi, D.O., S.M. Olson, D.J. Mitchell, I. Secker, and R. McSorley. 1997. Adaption of soil solarization to the integrated management of soilborne pests of tomato under humid conditions. Phytopathology 87:250-258.

Di Gioia, F., F. Serio, D. Buttaro, O. Ayala, and P. Santamaria. 2010. Influence of rootstock on vegetative growth, fruit yield and quality in 'Cuore di Bue', an heirloom tomato. J. Hort. Sci. Biotechnol. 86:477-482.

Driver, J.G. and F.J. Louws. 2002. Fumigants and varieties to manage southern bacterial wilt of tomato. 2002 Annu. Intl. Res. Conf. Methyl Bromide Alternatives Emissions Reductions, Orlando, FL, 6-8 Nov. 2002. p. 228-232.

Enfinger, J.M., S.M. McCarter, and C.A. Jaworski. 1979. Evaluation of chemicals and application methods for control of bacterial wilt of tomato transplants. Phytopathology 69:637-640.

Gardner, W., E.P. Mulvey, and E.C. Shaw. 1995. Regression analyses of counts and rates: Poisson, overdispersed Poisson and negative binomial models. Psychol. Bull. 118:392-404.

Hardy, D.H., M.R. Tucker, and C.E. Stokes. 2014. Crop fertilization based on
North Carolina soil tests. North Carolina Dept. Agr. Consumer Serv. Circ. No. 1.

Hayward, A.C. 1991. Biology and epidemiology of bacterial wilt caused by Psuedomonas solanacearum. Annu. Rev. Phytopathol. 29:65-87.

Ivors, K. 2010. Commercial production of staked tomatoes in the southeast. North Carolina Coop. Ext. Serv. Bul. AG405. 3rd ed.

Ji, P., C. Allen, A. Sanchez-Perez, J. Yao, J.G. Elphinstone, J.B. Jones, and M.T. Momol. 2007. New diversity of Ralstonia solanacearum strains associated with vegetable and ornamental crops in Florida. Plant Dis. 91:195-203.

Kemble, J.M., L. Ivey, K.M. Jennings, and J.F. Walgenbach (eds.). 2016. 2016 Vegetable crop handbook for southeastern United States. Farm Journal Media, Lenexa, KS.

Kyriacou, M.C., Y. Rouphael, G. Colla, R. Zrenner, and D. Schwarz. 2017. Vegetable grafting: The implications of a growing agronomic imperative for vegetable fruit quality and nutritive value. Front. Plant Sci. 8:741.

Lee, J.M. 2003. Advances in vegetable grafting. Chronica Hort. 43:13-19.

Lee, J.M., H.J. Bang, and H.S. Ham. 1998. Grafting of vegetables. J. Jpn. Soc. Hort. Sci. 67:1098-1104.

Leonardi, C. and F. Giuffrida. 2006. Variation of plant growth and macronutrient uptake in grafted tomatoes and eggplants on three different rootstocks. Eur. J. Hort. Sci. 71:97-101.

Louws, F.J., C.L. Rivard, and C. Kubota. 2010. Grafting fruiting vegetables to manage soilborne pathogens, foliar pathogens, arthropods and weeds. Scientia Hort. 127:127-146.

Martin, F. 2003. Development of alternative strategies for management of soilborne pathogens currently controlled with methyl bromide. Annu. Rev. Phytopathol. 41:325-350.

McAvoy, T., J.H. Freeman, S.L. Rideout, S.M. Olson, and M.L. Paret. 2012. Evaluation of grafting using hybrid rootstocks for management of bacterial wilt in field tomato production. HortScience 47:621625 .

Mišković, A., Z. Ilin, and V. Marković. 2009. Effect of different rootstock type on quality and yield of tomato fruits. Acta Hort. 807:619-624.

Nion, Y.A. and K. Toyota. 2015. Recent trends in control methods for bacterial wilt diseases caused by Ralstonia solanacearum. Microbes Environ. 30:1-11. 
Rivard, C. and F.J. Louws. 2008. Grafting to manage soilborne diseases in heirloom tomato production. HortScience 43: 2104-2111.

Rysin, O. and F.J. Louws. 2015. Decision tool for growers to evaluate economic impact of grafting technology adoption: An application to open-field conventional tomato production. HortTechnology 25: $132-138$.

Scott, J.W., J.F. Wang, and P.M. Hanson. 2005. Breeding tomatoes for resistance to bacterial wilt, a global view. Acta Hort. 695:161-172.

Shiomi, Y., M. Nishiyama, T. Onizuka, and T. Marumoto. 1999. Comparison of bacterial community structures in the rhizoplane of tomato plants grown in soils suppressive and conducive towards bacterial wilt. Appl. Environ. Microbiol. 65: 3996-4001.
Suchoff, D., C. Gunter, J. Schultheis, and F.J. Louws. 2015. On-farm grafted tomato trial to manage bacterial wilt. Acta Hort. 1086:119-127.

U.S. Department of Agriculture. 1991. United States standards for grades of fresh tomatoes. 19 Dec. 2016. <https://www. ams.usda.gov/sites/default/files/ media/Tomato_Standard\%5B1\%5D. pdf $>$.

U.S. Department of Agriculture. 2016. Vegetables 2015 summary. 19 Dec. 2016. <https://www.nass.usda.gov/ Publications/Todays_Reports/reports/ vegean 17.pdf $>$.

U.S. Department of Agriculture. 2014. Description of commercial tomato rootstocks as of 11 Feb. 2014. 19 Dec. 2016. <http://www.vegetablegrafting.org/ wp/wp-content/uploads/2014/06/ usda-scri-combined-rs-tables-feb- 14 . pdf>.

U.S. Environmental Protection Agency. 2011. The phaseout of methyl bromide. 19 Dec. 2016. <http://www.epa.gov/ ozone/methyl-bromide/>.

Wang, J.F., P. Hanson, and J.A. Barnes. 1998. Worldwide evaluation of an international set of resistance sources to bacterial wilt in tomato, p. 269-275. In: C. Allen and J. Elphinstone (eds.). Bacterial wilt disease. Springer, Berlin/ Hedelberg, Germany. 